\title{
MERETAS RANCANG BANGUN TEOLOGI MULTIKULTURAL
}

\section{Gunaryo Sudarmanto ${ }^{168}$}

\begin{abstract}
:
Hubungan budaya dan teologi dipahami secara beragam. Deskripsi budaya secara sempit telah membedakan dan memisahkannya dari teologi. Sebaliknya deskripsi teologi yang sempit juga mengesampingkan budaya. Tulisan ini bermaksud mendeskripsikan budaya dan teologi secara proporsional baik secara umum maupun alkitabiah. Kemudian mendeskripsikan korelasi antara budaya dan teologi serta menetapkan apa peran teologi terhadap budaya. Khususnya dalam konteks paradigma 'multikultur' yang sarat dengan konflik antar etnis dan religi di dunia pada umumnya dan Indonesia pada khususnya, bagaimana teologi berperan memberi alternatif solusi. Untuk itu diusulkan terbentuknya rancang bangun 'Teologi Multikultur' yaitu suatu teologi yang didisain berbasis prinsipprinsip alkitab yang menjadi pedoman bagi orang kristen dalam membangun hubungan dengan orang lain yang berbeda etnis dan religi. Prinisp-prinsip tersebut bermaksud untuk mempertemukan segala perbedaan dalam masyarakat pada tataran etis, yang didasarkan pada prinsip teologis.
\end{abstract}

\section{Kata Kunci:}

Teologi, Paradigma, Kultur, Multikultur

\section{Pendahuluan}

Berteologi dan berbudaya acapkali dianggap sebagai dua aktifitas yang terpisah karena keduanya diklaim memiliki karakteristik yang berbeda. Secara ekstrim ada yang memilih sikap 'dualistik' dimana keduanya dipandang sebagai fenomena yang berbeda sama sekali. Dalam perspektif seperti itu, berteologi berarti hanya berurusan dengan Tuhan saja (vertikalisme). Sedangkan berbudaya adalah aktifitas antar sesama manusia dan lingkungannya (horisontalisme). Memang selain sikap dualistik, sejarah gereja mencatat beragam sikap iman Kristen (baca: 'berteologi') terhadap budaya. Ada sikap 'Antagonis' 168 Rektor Institut Injil Indonesia, Batu, Jawa Timur. 
yaitu sikap menentang kebudayaan. Ada sikap 'Akomodatif' yaitu sikap dimana gereja mengakomodir budaya. Ada juga sikap 'dominatif' yaitu sikap gereja yang mendominir nilainilai dan praktik budaya. Namun ada juga sikap 'revisionis' dimana iman Kristen berperan 'merevisi' budaya.

Sejatinya aktifitas berteologi dan berbudaya terfokus pada 'subyek' yang sama yaitu 'manusia'. Manusialah yang berteologi dan berbudaya. Karena keduanya dilakukan oleh pribadi yang sama, maka interaksi keduanya tak terhindarkan. Itu sebabnya para teolog berteologi bersama budaya. Sebaliknya, para budayawan tak dapat menghindarkan budaya dari aspek teologi. Yang menjadi pertanyaan adalah bagaimana keduanya dikorelasikan? Bagi teolog Kristen, berteologi berarti memandang dan mengelola budaya manusia dalam perspektif iman Kristen yang berbasis pada Alkitab. Dalam arah itu, para teolog telah dan sedang berteologi sekaligus berbudaya. Misalnya karya-karya tahun 1950-an, Richard Niebuhr menulis bukunya yang berjudul "Christ and Culture” (1951). Paul Tillich juga menulis buku berjudul "Theology of Culture" (1954). Karya-karya selanjutnya yang menyusul di antaranya: karya Charles Kraft berjudul "Christianity and Culture" (1979), karya Aylward Shorter berjudul "Toward a Theology of Inculturation" (1988), dan karya Louis Luzbetak berjudul "The Church and Cultures” (1988).

Karena itu tulisan ini bermaksud mengonfirmasi hakikat peran atau fungsi teologi terhadap budaya. Untuk itu, perlu dideskripsikan terlebih dahulu pengertian 'budaya' secara umum dan alkitabiah, paradigma multikultur, dan kemudian dijelaskan bagaimana tugas teolog dalam merancang bangun teologi multikultural.

\section{Pengertian 'Budaya' (Kultur).}

Kata 'budaya' berpadanan dengan kata 'kultur' yang berasal dari kata Latin: 'cultura'l69 dengan akar kata: 'colo, colere' yang artiya:“membuat, mengolah, mengerjakan,

169Philip Babcock Gve (Ed.), Webster's Third New International Dictionary ((USA: meriam Inc. Publisher, 1983), 552. 
menanam, menghias, mendiami". ${ }^{170}$ Dari arti dasar tersebut, bangsa Romawi menggunakannya dalam relasinya dengan pengerjaan tanah (agricultur: pertanian), pemeliharaan, pengembangan dan penyemaian bakat rohani (cultura-animi). ${ }^{171}$ Bahasa Indonesia mengadopsi kata cultura (Inggris: culture) menjadi 'kultur' untuk menyebutkan hal-hal yang berhubungan dengan pengusahaan dan pemeliharaan hal-hal material seperti: sawah, ladang, tanah liat, batu, tubuh manusia dan hewan. Namun kemudian pengertian kata 'kultur' juga digunakan untuk hal-hal rohani, akal budi, kesenian, ilmu pengetahuan dan sebagainya. Dalam bahasa Indonesia kata 'kultur' sering disebut juga sebagai "peradaban, cara hidup dan kebudayaan." dimengerti sebagai 'kebudayaan'.

Istilah 'kebudayaan' itu sendiri dibentuk dari kata dalam bahasa Sansekerta, yaitu: 'budi' dan 'daya'. Kata 'budi' dimengerti sebagai 'roh' atau 'akal', sehingga tidak hanya dimengerti sebatas rasio. Pada dasarnya kebudayaan menunjuk kepada segala sesuatu yang diciptakan oleh budi manusia. ${ }^{173}$ Dalam perkembangannya pengertian kebudayaan menjadi sangat beragam. Ada yang mendefinisikannya secara sempit yaitu sebatas 'kesenian' saja. Sebaliknya, para antropolog dan sosiolog mengartikannya secara luas. Edward Tailor mendefinisikan, "Culture is that complex whole included knowledge, belief, art, morals, law, custom and any other capabilities and habits aquared by man as member of society". ${ }^{174}$ Definisi tersebut dikembangkan lagi menjadi, "Culture is learned and shared attitudes, values, and way of behavior of the members of society". ${ }^{175}$ Itu menunjukkan bahwa ruang lingkup kata 'kultur' mencakup seluruh aspek dari kehidupan manusia. Mengingat pengertian kebudayaan yang sedemikian luas, maka Kuntjoroningrat mensinyalir adanya 160 definisi tentang kebudayaan. Namun Kuntjoroningrat sendiri mengklasifikasi bahwa pada dasarnya kebudayaan itu berisi,"sistem religi dan upacara keagamaan, sistem organisasi kemasyarakatan, sistem pengetahuan, bahasa, kesenian, sistem mata pencaharian, sistem 170 J. Verkuyl, Etika Kristen: Kebudayaan (Jakarta: BPK Gunung Mulia, 1982), 12.

171 lbid., 12

172 lbid., 12-13.

173 Ibid., 13.

174 Stephen Grunlan \& Milton Reiner (ed.), Christian Perspective on Sociology (Grand Rapids, Michigan: Zondervan Publishing House, 1982), 47.

175 lbid, 48. 
teknologi dn peralatan." Kesemuanya itu mewujud dalam kompleks ide-ide atau nilai-nilai, kompleks aktivitas kelakuan berpola dan benda-benda hasil karya. Dari wujud tersebut diketahui bahwa kultur meliputi baik yang bersifat 'material' maupun 'non material'. Akhirnya ia sendiri menyimpulkan kebudayaan sebagai,"Keseluruhan gagasan dan karya manusia, yang harus dibiasakan dengan belajar, beserta keseluruhan dari hasil budi dan karyanya itu". ${ }^{176}$ Kesimpulan tersebut menunjukkan aspek 'asal' atau 'dasar' budaya, proses budaya dan hasil budaya. Sementara itu William J. Larkin, Jr., menyimpulkan pengertian kebudayaan dari beberapa antropolog terkini dengan definisi:

Culture is that integrated pattern of socially acquired knowledge, particularly Ideas, belief, and values (ideology) mediated through language, which a people uses to interpret experience and generate patterns of behavior-technological, economic, social, political, religious, and artistic - so that it can survive by adapting to relentlessly changing circumstances. ${ }^{177}$

Pada dasarnya definisi Larkin hendak merangkum aspek-aspek hidup manusia secara menyeluruh.

Selain para Antropolog dan Sosiolog, para teolog juga memandang kebudayaan secara luas. Misalnya, Louis Luzbetak dalam bukunya "The Church and Culture" seperti dipaparkan ulang oleh Agus G. Satyaputra:

Budaya adalah "a design for living” yang merupakan suatu rencana dimana sebuah masyarakat mengadaptasikan diri kepada lingkungan fisik, sosial dan ide. Rencana untuk mengatasi lingkungan fisik meliputi hal memproduksi makanan, semua pengetahuan dan ketrampilan teknologi. Sistem politik, kekerabatan dan organisasi keluarga serta hukum merupakan contoh dari adaptasi sosial yakni rencana yang menyangkut hubungan dengan orang lain. Sedangkan cara manusia

176Koentjoroningrat, Kebudayaan Mentalitet dan Pembangunan (Jakarta: PT Gramedia, 1979), 19.

177William J. Larkin, Jr, Culture and Biblical Hermeneutic (Grand Rapids: Baker Book House, 1988), 192-193. 
mengatasi lingkungan ide adalah melalui pengetahuan, seni, ilmu magis, ilmu pengetahuan, filsafat dan agama. Secara essensial, budaya merupakan jawaban terhadap masalah-masalah manusia. ${ }^{178}$

Meski Luzbetak mencoba merinci korelasi di antara aspek-aspek dalam kehidupan masyarakat, namun secara esensial ia menyetujui bahwa budaya meliputi keseluruhan aspek hidup manusia. Hanya saja ia memberi penekanan bahwa budayalah yang mendisain kehidupan. Dengan kata lain tanpa budaya tidak mungkin ada suatu tata kelola kehidupan manusia.

Seluruh pengertian di atas menunjukkan bahwa kebudayaan mencakup seluruh aspek hidup manusia atau dapat dikatakan kebudayaan merupakan aktualisasi totalitas eksistensi manusia itu sendiri.

\section{Budaya Dalam Perspektif Alkitab}

Alkitab juga dapat dikatakan sebagai hasil budaya. Selain berisi nilai-nilai, Alkitab juga menjelaskan adanya proses dan hasil karya budaya. Alkitab menarasikan proses hidup manusia lengkap dengan aspek-aspek budayanya. Karena itu, Alkitab tidak dapat dipisahkan dari aspek budaya.

Bila kultur dimengerti sebagai totalitas hidup manusia, maka kultur itu sendiri sudah ada sejak manusia ada dari mulanya. Ketika Allah menciptakan manusia pada hari yang keenam (Kej 1:26-27), setelah seluruh alam semesta dijadikan, manusia merupakan makhluk yang berbudaya. Artinya, mereka telah mampu mengaktualisasi diri merespon segala yang

178Louis Luzbetak, The Church and Cultures (Pasadena: William Carey Library,1970), 60-61. 
ada di sekitarnya, baik kepada Allah, sesamanya manusia maupun alam semesta. Karena itu, Allah memberi tugas budaya kepada mereka. Verkuyl menjelaskan hal ini:

\begin{abstract}
Allah yang hidup adalah Allah yang menciptakan manusia dengan mata yang dapat melihat, dengan otak yang dapat berpikir, dengan tangan yang dapat membangun, supaya manusia itu, atas nama Tuhan, menakhlukkan dunia kepadanya. Allah Sang Pencipta, adalah pula Pemberi tugas kebudayaan. ${ }^{179}$
\end{abstract}

Penjelasan tersebut hendak menegaskan adanya potensi pada diri manusia yang memungkinkannya untuk berkreasi memelihara keberlangsungan kehidupannya. Pada umumnya, para teolog dan etikus, memulai pembicaraan mengenai kebudayaan dari Kejadian 1:28 yang kemudian disebut sebagai Mandat Kebudayaan yang lengkapnya berbunyi:

Allah memberkati mereka lalu Allah berfirman kepada mereka: "Beranakcuculah dan bertambah banyak; penuhilah bumi dan takhlukkanlah itu, berkuasalah atas ikan-ikan di laut dan burung-burung di udaradan atas segala binatang yang merayap di bumi”. ${ }^{180}$

Kata kunci ayat di atas ialah "kabash" ( Inggris: subdue) artinya, "takhlukkanlah atau jadikan mereka hamba". ${ }^{181}$ Kata ini dipakai 15 kali dalam PL yang diartikan 'menundukkan lawan' atau 'menakhlukkan lawan'. Bila ditelusuri akar kata kerjanya berarti 'menginjak'. Sebab itu, laki-laki diciptakan untuk memerintah dengan cara yang memperlihatkan kekuasaannya (jika perlu dengan paksa) dan kedudukannya sebagai tuan atas segala ciptaan. ${ }^{182}$ Kata ini bisa bermakna negatif karena bisa berarti penggunaan kekuatan secara sewenang-wenang. Namun dapat juga dalam pengertian positif yaitu: memikirkan, mengerjakan, mengusahakan, mengolah alam dengan melestarikannya. Dalam konteks Kejadian 1:28 pastilah Allah memaksudkan kata 'kabash' dalam arti positif agar dengan

\title{
179Verkuyl, 21
}

180Kejadian 1:28

181Francis Brown, SR Driver dan Charles A. Briggs, A Hebrew and English Lexicon of the Old Testament (Oxford: Claredon, 1962), 461.

182Roy B. Zuck, A Biblical Theology of The Old Testament (Malang: Gandum Mas, 2005), 36. 
mengelola alam secara bertanggung jawab manusia memenuhi segala kebutuhannya bahkan bermanfaat untuk generasi berikutnya. ${ }^{183}$

Mandat kebudayaan tersebut sudah diberikan Allah sebelum manusia jatuh dalam dosa. Allah menempatkan mereka di taman Eden untuk mengerjakan dan memelihara tanah itu (Kej 2:15). Di taman itulah untuk pertama kalinya manusia mengeksplorasi sumber kebudayaan dan sumber kerjanya. Karena itu bekerja adalah perintah Allah, bukan akibat dosa. Allah telah menjadikan kerja sebagai hakikat hidup manusia. ${ }^{184}$ Dengan mandat kebuduyaan itu, manusia mengembangkannya dalam semua bidang ilmu pengetahuan dan kebudayaan untuk tujuan memuliakan Allah dan menyatakan kasih kepada sesama manusia agar menjadi hamba Allah yang lebih benar, lebih pandai, dan lebih mulia. ${ }^{185}$ Namun setelah kejatuhan manusia dalam dosa mandat kebudayaan tersebut tidak pernah dicabut. A.F. Glasser menegaskan hal ini seperti dikutip oleh Petrus Octavianus:

"Walaupun manusia jatuh ke dalam dosa, amanat kebudayaan tidak pernah ditarik kembali...Manusia bahkan di dalam kejatuhannya sekalipun tetap berada terus di bawah kewajiban serta dorongan ilahi untuk menemukan serta memakai kekuatan-kekuatan alam di sekitarnya dan untuk melibatkan dirinya di segala segi keberadaan manusia." 186

Untuk itu dalam keberdosaannya manusia terus melaksanakan mandat kebudayaannya. Alkitab mencatat berbagai keahlian yang dikembangkan manusia, seperti: Yabal sebagai orang yang tinggal di kemah dan peternak, Yubal sebagai pemain kecapi dan seruling, dan Tubal Kain sebagai penempa tembaga dan besi (Kej 4:17-22). Namun demikian, karena akibat dosanya manusia tidak lagi menghasilkan kebudayaan yang selaras dengan kemuliaan Tuhan. Karya budaya manusia justru memberontak Allah. ${ }^{187}$ Ini nampak dalam kehidupan generasi berikutnya, yaitu ketika Kain membunuh Habel karena kultusnya dengan mempersembahkan hasil kulturnya tidak diterima Allah (Kej 4). Selain peristiwa itu, pemberontakan 'menara Babel' juga menunjukkan aktualisasi budaya manusia yang

183Sihombing, 77-78

184A.A.Sitompul, Manusia dan Budaya (Jakarta: BPK Gunung Mulia, 1991), 4. 185Verkuyl, 2.

186Petrus Octavianus, Identitas Kebudayaan Asia Dalam Terang Firman Allah (Batu-Malang: YPPII, 1985), 12.

187Ibid., 12. 
memberontak Allah. Akibatnya mereka dikacaukan dan diserakkan dengan berbagai bahasa (Kej 11). Sejak itu pengaruh dosa telah merasuk ke seluruh aspek budaya manusia. Bahkan kebudayaan telah menjadi bagian integral keberdosaan. Stephen Tong menyebut keadaan itu dengan menyatakan,"Kebudayaan telah didistorsi oleh dosa, bayang-bayang kejatuhan berada di dalam kebudayaan." ${ }^{188}$ Hubungan antara 'kultur' dan 'kultus' manusia telah rusak. ${ }^{189}$ Bahkan segala kecenderungan hati manusia membuahkan kejahatan semata-mata, sehingga telah membuat Allah merasa menyesal telah menciptakan manusia (Kej 6:7).

Namun demikian Allah tetap mengasihi manusia. Ia tetap merindukan untuk bersekutu dengan manusia yang diciptakan-Nya menurut gambar dan rupa-Nya (Kej 1:2627). Sesaat setelah kejatuhan Adam dan Hawa, Ia segera menyatakan rencana karya penyelamatan-Nya dalam Kejadian 3:15 yang kemudian dikenal sebagai 'proto euanggelion'. Rancangan penyelamatan Allah itu mulai dinyatakan dengan pemilihan dan panggilan Abraham sebagai bapa orang beriman (Kej 12) dan melahirkan bangsa Israel yang dipilih sebagai umat-Nya. Puncak karya-Nya digenapi di dalam dan melalui Yesus Kristus sebagai inkarnasi Allah (Yoh 1:1-3, 14). Melalui karya salib-Nya (Flp 2:6-8) Allah menebus manusia berdosa untuk melepaskan mereka dari kuasa kegelapan dan memindahkannya ke dalam kerajaan Anak-Nya yang kekasih (Kol 1:13). Siapa yang menerima Kristus telah menjadi ciptaan baru (2Kor 5:17) dan terus menerus mengalami pembaharuan budinya (Rm $12: 2)$.

Karya Kristus telah memungkinkan pemulihan relasi antara manusia dengan Allah yang terputus akibat dosa. Pemulihan hubungannya dengan Allah ini terefleksi dalam seluruh kebudayaannya, karena karya Kristus juga memulihkan seluruh aspek kebudayaannya untuk kembali kepada kemuliaan Allah. Petrus Octavianus menyatakan:

Peranan orang Kristen dalam kebudayaan adalah unik. Sebab oleh anugerah Allah di dalam Yesus Kristus, matanya dicelikkan kepada pernyataan Allah yang khusus tentang kehendak Allah bagi umat manusia. Setelah menjawab penggilan Allah, seharusnya orang Kristen tidak meninggalkan kebudayaannya. Tetapi menilainya kembali dalam terang firman Allah yang supra-kulturil dan multikulturil (Supra-kultural karena merupakan kaidah yang mutlak untuk

188Stephen Tong, Dosa dan Kebudayaan (Surabaya: Momentum, 2007), 79. 189Sihombing, 79. 
menilai segala kebudayaan dan peradaban manusia. Multi-kulturil sebab mencakup semua kebudayaan dan juga relevan terhadap semua kebudayaan). ${ }^{190}$

Karena itulah manusia yang telah diperbaharui memiliki sikap yang baru dalam memandang kebudayaan, seperti dilakukan Yesus Kristus ketika hidup sebagai orang Yahudi dan tinggal dalam konteks budaya Yahudi. Sikap Yesus terhadap kebudayaan ini sudah dijelaskan oleh H Richard Nieburh dalam bukunya Christ and Culture dalam lima sikap yaitu: 1) Christ against culture (Kristus lawan kebudayaan), 2) Christ of Culture (Kristus dari kebudayaan, 3) Christ above culture (Kristus di atas kebudayaan), 4) Christ and culture in paradox (Kristus dan kebudayaan dalam paradoks), 5) Christ, the transformer of culture (Kristus mentranformasi kebudayaan). ${ }^{191}$ Sedangkan Charles H. Kraft dalam bukunya, Christianity in Culture: A Study in Dynamic Biblical Theologizing in Cross Cultural Perspective memperluas klasifikasi Niebuhr. Menurut Kraft, 1) Posisi Allah melawan kebudayaan ada dua macam yaitu: Allah sebagai Pahlawan budaya dan Allah sebagai Penganjur salah satu kebudayaan, 2) Posisi Allah di atas kebudayaan dibagi dalam lima sikap: Allah di atas kebudayaan dan tidak peduli terhadapnya, pandangan sintetik, dualis, conversionis, dan Allah di atas tetapi melalui kebudayaan.

Kraft sendiri berdiri pada pandangan yang ia sebut "The God above but through culture position". ${ }^{192}$ Allah dipahami bersifat transenden-absolut yang secara mutlak berada di luar budaya. Allah berada di atas semua budaya namun memakai budaya untuk berinteraksi dengan manusia. Budaya itu sendiri secara esensial bersifat netral dan menjadi alat bagi manusia meskipun telah dipengaruhi dosa, sehingga penggunaan seluruh aspek budaya tidak lagi murni. Tentang hal ini Kraft memandang kebudayaan sebagai sesuatu yang berada di luar diri manusia yang bersifat netral. Sherwood Lingenfelter tidak sependapat mengenai kenetralan budaya ini. Menurutnya, Kraft kurang menangkap presensi dosa dalam dosa dalam pikiran dan kehidupan manusia. Budaya bagaikan 'slot machine' yang hanya melayani interes dan keuntungan pribadi dan kelompok. ${ }^{193}$

1900ctavianus, 15.

191H. Richard Niebuhr, Christ and Culture (New York: Harper and Row, Harper Torchbooks, 1956).

192Charles H. Kraft, Christianity in Culture: A Study in Dynamic Biblical Theologizing in Cross Cultural Perspective (New York: Orbis Book, 1992), 103-113.

193Sherwood Lingenfelter, Transforming Culture: A Challenge for Christian Mission (Grand Rapids: Baker Book House, 1992), 18. 
Namun pada prinsipnya Allah yang menciptakan budaya, sehingga Ia berada di luar budaya, tetapi Ia bekerja di dalam dan melalui budaya. Ia tidak dikuasai budaya, melainkan secara bebas memilih menggunakan budaya untuk berinteraksi dengan manusia. Ia tetap menghendaki agar manusia berdosa diselamatkan bersama seluruh aspek-aspek budaya pada dirinya, sehingga melalui pembaharuannya itu orang percaya menjadi transformator terhadap kebudayaan manusia.

Sikap Allah terhadap kebudayaan ini telah diimplementasikan dengan sikap yang berbeda dalam sejarah gereja. Verkuyl mencatat lima sikap gereja terhadap kebudayaan, yaitu: ${ }^{194}$

1. Sikap Antagonistis (sikap menentang). Sikap ini merupakan sikap negatif terhadap kebudayaan, yaitu melihat adanya pertentangan yang tak terdamaikan antara iman Kristen dengan kebudayaan. Sikap seperti ini terjadi pada abad permulaan gereja, sehingga Tertulianus mengucapkan, "Apakah sangkut paut Yerusalem dengan Athena". Maksudnya, antara iman Kristen dan kebudayaan tidak ada kompromi, karena semua kebudayaan ada ikatan dengan penyembahan berhala. Karena itu segala bentuk permainan, tari, sandiwara, kemiliteran dan lain-lain harus dihindari.

2. Sikap Akomodasi dan kapitulasi. Sikap ini menunjukkan adanya upaya menyesuaikan diri dengan kebudayaan yang ada. Akibatnya hakikat kekristenan dikorbankan demi kepentingan kebudayaan yang ada. Misalnya, di abad ketiga, dalam tulisan tentang teologi dan filsafat, Clement dari Alexandria dan Origenes berupaya menyesuaikan Injil dengan isi filsafat Plato. Hal serupa dilakukan Petrus Abelardus (1079-1142) yang mengganti 'iman' dengan 'rasio' untuk menentukan segala sesuatu. Akibatnya ia membuktikan bahwa ajaran Yesus "sesuai benar dengan apa yang diajarkan oleh Sokrates dan Plato".

3. Sikap Dominasi. Sikap ini menunjukkan adanya dominasi gereja terhadap kebudayaan, baik secara teori maupun praktiknya. Sikap ini sangat menonjol dalam masa Katolik Roma yang sangat mendominir kebudayaan Katolik Roma. Sikap ini didasarkan pada pandangan Thomas Aquinas mengenai perbedaan ordo naturalis dan ordo supranaturalis. Karena dosa, manusia kehilangan anugerah supranaturalis, namun kodrat naturalisnya tidak rusak sehingga masih dapat memelihara kebaikan dan kecakapan lainnya sebagai 
manusia. Namun menurut Thomas, tujuan hidup manusia bukan kepada ordo naturalis (kebudayaan) melainkan kepada ordo supranaturalis (anugerah- gereja). Jalan untuk mecapai tujuan itu ialah sakramen gerejawi. Karena itu kebudayaan, secara hierarkhis, harus berada di bawah gereja. Kebudayaan harus 'disucikan' oleh gereja.

4. Sikap Dualistis (mendua). Sikap ini bermaksud memisahkan sama sekali iman Kristen dan kebudayaan. Keduanya berdiri sendiri-sendiri tanpa berelasi. Sikap ini berpendapat bahwa dalam hidup orang Kristen ada kepercayaan kepada pekerjaan Allah di dalam dan melalui Yesus Kristus. Tetapi pada saat yang sama, manusia sendiri bisa berdiri sendiri dengan usaha kebudayaannya Anugerah tidak mempengaruhi kebudayaan manusia. Sikap ini nampak dalam pandangan Marcion, di masa gereja mula-mula, mengenai 'dua Allah', yaitu: Allah pencipta langit bumi yang penuh anugerah dan 'demiurgos' sebagai 'allah' penguasa alam (budaya). Keduanya tidak saling mempengaruhi. Dalam budaya tidak terdapat tanda-tanda pengaruh rahmat Allah.

5. Sikap Pengudusan. Sikap ini menekankan pentingnya 'pengudusan' di bidang kebudayaan oleh anugerah Allah. Sikap ini didasarkan pada prinsip kesatuan asasi antara ciptaan (creation) dan pembaharuan ciptaan (recreation). Allah datang untuk menyelamatkan alam dari dosa dan iblis. Ia menguduskan manusia berdosa menjadi manusia baru supaya menjadi terang dan garam bagi dunia (kebudayaan) manusia yang gelap.

Dengan ragam sikap iman Kristen terhadap kebudayaan tersebut, maka untuk memudahkan menentukan sikap yang harus dipilih Donald Mc Gavran membedakan kekristenan dalam empat wilayah. Christianity One, adalah wilayah yang meliputi doktrin kepercayaan tentang Allah, kehidupan kekal, kebenaran, keselamatan dalam Kristus dan berbagai doktrin fundamental. Di wilayah ini semua aspek budaya harus tunduk di bawah kebenaran-kebenaran absolut. Christianity Two, merupakan wilayah Etika Kristen, yaitu aplikasi praktis sistem evaluasi norma yang sifatnya relatif atau bergantung kepada nilai kultural setempat. Christianity Three, merupakan wilayah yang meliputi hal-hal tradisi gereja dalam beribadat, liturgi, lagu-lagu yang dinyanyikan, dan bentuk arsitektur gereja. Christianity Four, merupakan wilayah tradisi gereja lokal. Jadi menurut McGavran, sikap 
gereja terhadap kebudyaan sangat ditentukan oleh wilayah Christianity mana yang sedang dihadapi. ${ }^{195}$

Jadi, Allah menciptakan manusia menurut gambar dan rupa-Nya yang diperlengkapi dengan kemampuan mengaktualisasi diri dalam hubungannya dengan Tuhan, dirinya sendiri, dan alam sekitarnya untuk keberlangsungan hidupnya. Karena itulah manusia disebut sebagai makhluk yang berbudaya. Namun karena dosa mengakibatkan seluruh aspek kebudayaannyapun dipengaruhi dosa, sehingga tidak lagi tertuju memuliakan Allah. Meski demikian Allah tetap mengasihi manusia, maka Ia berinkarnasi di dalam dan melalui Yesus Kristus untuk menyelamatkannya beserta seluruh aspek budayanya. Penyelamatan ini merupakan pemulihan relasi baik dengan Allah, sesamanya dan alam lingkungannya. Untuk itu orang yang sudah diselamatkan oleh karya pengudusan Kristus akan berfungsi merefleksikan karya kristus di seluruh sektor kebudayaannya, agar manusia dan budayanya kembali memuliakan Allah Sang Pencipta.

\section{Paradigma 'multikultur'.}

Pada masa kini, budaya tidak lagi dipahami sebagai 'monokultur' melainkan 'multikultur' yaitu suatu fenomena keragaman budaya dalam sebuah komunitas tertentu. Istilah 'multikultur' digunakan untuk menggambarkan kesatuan berbagai etnis masyarakat yang berbeda dalam suatu negara.

Indonesia juga merupakan negara dengan sistem sosial dan budaya yang beraneka ragam. Multikulturalitas bangsa Indonesia telah menempuh perjalanan sejarah yang amat panjang. Jauh sebelum masa kolonialisme Eropa masuk ke Nusantara, keanekaragaman itu sudah menjadi pengalaman berbudaya di Nusantara. Banyak monumen historis yang dapat 
dicatat sebagai bukti adanya multikulturalitas bangsa. Misalnya, pendirian Candi Borobudur sebagai salah satu pusat ibadah kaum Budhis ternyata dibangun pada masa Dinasti Syailendra yang beragama Hindu Syiwa. Fakta tersebut membuktikan bahwa keanekaragaman itu sudah terpatri sebagai sikap normatif dalam melihat diversitas masyarakat. Disinyalir kelompokkelompok beragama di Indonesia sudah berkembang sebagai sistem keagamaan lokal yang terus dipelihara oleh pemeluknya. Agama-agama lokal ini menyebar di berbagai wilayah propinsi. Diperkirakan jumlah suku bangsa di Indonesia mencapai lebih dari enam ratus entitas. Jika masing-masing komunitas tersebut memiliki sistem keyakinan keagamaannya sendiri-sendiri, maka dapat disimpulkan betapa kuatnya keragaman sistem keagamaan di Indonesia. ${ }^{196}$

Pada masa pemerintahan Hindia Belanda, bangsa Indonesia juga mengalami kemajuan di bidang pemeliharaan sikap dan toleransi dalam mengakui diversitas di masyarakat. Walaupun Islam memasuki Nusantara diiringi dengan pertumpahan darah di beberapa tempat, namun puritanisme dan ortodoksi dalam beragama tidak menjadi pilihan utama massa-rakyat di Nusantara. Di Jawa misalnya, tradisi dan ritual pra-Islam masih diminati bahkan diakomodasi sebagai bagian dari nilai-nilai Islam Jawa. Di beberapa tempat, unsur lokalitas juga mendapat penghargaan yang sama seperti di Sulawesi Selatan, Bali, Nusa Tenggara Barat, dan lain-lain. ${ }^{197}$ Itu berarti hampir tidak ditemukan lagi suatu nilai budaya tunggal dalam komunitas budaya.

Pemahaman tentang diversitas juga dapat ditelusuri dari forum yang cukup fenomenal karena sukses mempertemukan beberapa pemuda dari berbagai daerah di Nusantara. Forum itu kemudian dikenal dengan "Sumpah Pemuda 1928". Forum tersebut berhasil mengumpulkan berbagai pemuda, sekaligus membuat ikrar bersama yang dikenal teksnya sekarang sebagai, teks Sumpah Pemuda. Ketika Kolonialisme mendapat ancaman krisis moneter global di sekitar paruh pertama abad ke-20, jaringan elite pribumi semakin meningkatkan konsolidasinya di tengah keanekaragaman budaya, agama, dan etnisitas

196 SEKOLAH MULTIKULTURAL DESANTARA (ANGKATAN 2008), Belajar Bersama Menulis Keanekaragaman Masyarakat Berdasarkan Pengalaman dan Perspektif Multikultural 
masyarakat. Misalnya ketika momentum pembentukan dasar dan falsafah negara Pancasila dalam proses perdebatan, elemen-elemen yang terlibat nyaris mengenyampingkan gagasangagasan ekstrim yang kontraproduktif dengan sifat keanekaragaman masyarakat Indonesia. Ini membuktikan bahwa Pancasila yang kemudian disepakati dengan lima sila, sebagian besar diserap berdasarkan aspirasi masyarakat yang bhinneka. ${ }^{198}$

Sayangnya, sejarah keindahan mozaik keanekaragaman di atas semakin pupus oleh kebijakan politik dari rezim yang menyebalkan. Kebijakan penertiban, pendisiplinan bertubitubi muncul di masa Soeharto. Orde Baru bahkan dikenal sebagai rezim otoriter. Konstitusi yang dijabarkan ke dalam sistem perundang-undangan gagal memediasi secara obyektif dan netral dalam mengelola perbedaan dan pertentangan kepentingan antar kelompok di masyarakat. Kebijakan bernuansa SARA bahkan melekat secara erat selama kepemimpinan Soeharto. Kelompok Cina misalnya kesulitan mendapatkan akses yang setara dalam pelayanan publik, seperti di bidang pendidikan, pencatatan sipil, dan kebebasan beragama. Kriminalisasi agama dalam bentuk delik penodaan agama (blasphemy) sering digunakan untuk menciduk kelompok/individu yang dianggap sesat, membahayakan kepentingan umum karena aliran kepercayaan, atau nilai-nilai keagamaan yang ia anut. ${ }^{199}$

Pendeknya, kehidupan agama dan kebudayaan di Indonesia semakin terancam karena diversitas semakin memudar lantaran kesalahan membuat kebijakan. Faktanya sampai saat ini, di era reformasi ini, kondisi kebebasan beragama dan diversitas di masyarakat masih belum berubah. Mendung masih menyelimuti suasana batin kelompok minoritas beragama, aliran kepercayaan dan komunitas-komunitas kecil yang masih dianggap 'liyan' (other). Kebebasan mereka terancam karena isu penodaan agama kerap meluncur dari fatwa MUI, aparat kepolisian dan Kejaksaan. Tidak jarang, milisi sipil terlibat aksi kekerasan sembari meneriakkan gema keagamaan. Menurut sebagian sumber, selama masa pemerintahaan SBYKalla, sudah terjadi lebih dari 170 kali aksi kekerasan terhadap kelompok agama/ budaya minoritas. ${ }^{200}$ 
Jadi multikulturalitas adalah fakta yang tidak bisa dipungkiri. Meskipun demikian, adanya fakta bahwa kehidupan di Indonesia memiliki sejumlah perbedaan, harusnya tidak merintangi terjaminnya hak hidup dan pengejewantahan nilai-nilai kemanusiaan individu dan kelompok di masyarakat. Multikulturalisme adalah konsep, paradigma, sekaligus pengalaman bagaimana diversitas ini dimaknai.

Di Indonesia penggunaan istilah 'Multikultural' juga dipakai dalam konteks politik yaitu dikaitkan dengan proses demokratisasi menuju masyarakat civil society yang kemudian juga banyak disinggung dalam hubungan dengan pelaksanaan Otonomi Daerah. Khususnya multikultural dipakai guna menangkal berbagai bentuk diskriminasi terhadap kelompok minoritas di suatu negara atau wilayah tertentu. ${ }^{201}$ Selain itu multikulturalisme juga dibicarakan lebih gencar di dunia pendidikan, karena pendidikan dianggap sebagai alat paling efektif penanaman nilai-nilai. Abdul Munir Mulkhan mendeskripsikan kondisi pendidikan multikultural sebagai berikut:

Pendidikan multikultural mengandaikan sekolah dan kelas dikelola sebagai suatu simulasi arena hidup nyata yang plural, terus berubah dan berkembang. Institusi sekolah dan kelas adalah wahana hidup dengan pemeran utama peserta didik di saat guru dan seluruh tenaga kependidikan berperan sebagai fasilitator. Pembelajaran dikelola sebagai dialog dan pengayaan pengalaman hidup unik, sehingga bisa tumbuh pengalaman dan kesadaran kolektif setiap warga dan peserta didik yang kelak menjadi dasar etika politik berbasis etika kewargaan. ${ }^{202}$

Dengan demikian pengertian dan penerapan istilah multikultural mencakup aspek-aspek yang sangat luas.

\section{Pembatasan Penggunaan Istilah Multikultural}

201mailto:gigihnusantaraid@yahoo.com Wawasan Multikulturalisme Indonesia Masih Rendah (Jakarta: INCIS, 2002), 1-2.

202Abdul Munir Mulkhan, "Pendidikan Monokultur Versus Multikultural dalam Politik" dalam Kompas, 28 September 2004 (Ed. KS). 
Melihat begitu luasnya aspek-aspek multikultural, maka untuk maksud tulisan ini, pengertian multikultur perlu dibatasi pada multietnis dan multireligi. Pembatasan ini didasarkan pada beberapa alasan, yaitu:

Pertama, Ini sesuai dengan keadaan yang dihadapi gereja masa kini, seperti yang ditegaskan dalam tulisan Gospel and Culture: New Focus for Mission, bahwa gereja sekarang memiliki jemaat yang berasal dari berbagai budaya, sehingga gereja terdorong untuk menjadi lebih multikultural. Karenanya agenda paling signifikan yang dihadapi gereja dalam konteks kontemporer adalah pergumulan gereja dengan budaya yang khusus, etnis, dan identitas keagamaan tertentu. ${ }^{203}$ Dengan kata lain gereja harus merespon secara kreatif dan sensitif fenomena multietnis dan multireligi. Kedua, etnis dan religi merupakan dua aspek kultural yang menjadi motif dasar berbagai konflik dan merupakan konteks masalah yang sedang dibicarakan, seperti telah dikemukakan di bagian terdahulu. Ketiga, pemilihan etnis bersesuaian dengan maksud pembicaraan ini yaitu untuk memproklamasikan Injil kepada segala bangsa (Mat. 28:19). Istilah 'segala bangsa' diterjemahkan dari frasa Yunani panta ta etne. Jadi yang dimaksud 'bangsa' ialah etne atau etnis (suku bangsa), dan kata 'segala' menunjuk jumlah yang banyak atau 'multi'. Sehingga panta ta etne dapat dikatakan menunjuk kepada pengertian multietnis yang berarti juga multikultur. Craig S. Keener mempertegas maksud Allah dalam hubungannya dengan multikultur seperti berikut:

Indeed, God is so involved in the multicultural matrix of history that he did not disdain to step into it himself. The ultimate enculturation of his Word occured when the Word became flesh, as the prologue of John (1:1-18) declares. Jesus did not come as a cultureless, amorphous, genderless human. He came as a firstcentury Jewish man, with unique chromosomes and physical features, just as each of the rest of us is unique. His cultural specificity does not means that he was not for all of us as a particular person - by being like we are - than by being a general, faceless person who compromised any real humanity for an indistinctive "neutrality".... One of the main emphases in the books of Acts is that the gospel is for all peoples and all cultures. The first Christian were surprised to learn that the gospel was for Gentiles as well as Jews, but

203“Gospel and Culture: New Focus for Mission" dalam Journal of Missiological \& Ecumenical Research, XXIII/2, 1994, 173. 
throughout the book of Acts the Spirit of God was revealing this multicultural mission to the church. ${ }^{204}$

Kutipan itu menunjukkan bahwa Allah yang menciptakan multikultur pernah hadir sebagai Person kultural di dalam Yesus Kristus untuk menyatakan diri-Nya untuk mengemban amanat misi multikultural (multietnis). Keempat, kultur tidak bisa dipisahkan dari aspek religi. Clifford Geertz, seorang antropolog, menganggap agama sebagai sebuah sistem kebudayaan. Menurutnya kebudayaan adalah:

Suatu pola makna-makna yang diteruskan secara historis yang terwujud dalam simbol-simbol, suatu sistem konsep-konsep yang diwariskan yang terungkap dalam bentuk-bentuk simbolis yang dengannya manusia berkomunikasi, melestarikan, dan memperkembangkan pengetahuan mereka tentang kehidupan dan sikap-sikap terhadap kebudayaan. ${ }^{205}$

Sedangkan yang ia maksudkan dengan agama adalah:

(1) sebuah sistem simbol-simbol yang berlaku untuk (2) menetapkan suasana hati dan motivasi-motivasi yang kuat, yang meresapi, dan yang tahan lama dalam diri manusia dengan (3) merumuskan konsep-konsep mengenai suatu tatanan umum eksistensi dan (4) membungkus konsep-konsep ini dengan semacam pancaran faktualitas, sehingga (5) suasana hati dan motivasi-motivasi itu tampak khas realistis. ${ }^{206}$

Dari kedua definisi tersebut nampak bahwa kebudayaan dan agama tidak dapat dipisahkan, karena keduanya dianggap bersentuhan dengan simbol-simbol. Para teolog juga sudah lama menyetujui ketakterpisahan agama dan kebudayaan. TS Elliot dalam bukunya

204Craig S. Keener, The IVP Bible Background Commentary New Testament ( Illinois : Inter Varsity Press, 1993), 26-27.

205Clifford Geertz, Kebudayaan dan Agama (Yogyakarta: Kanisius, 1992), 3. 206lbid., 5. 
Notes Toward the Definition of Culture menyatakan bahwa natur kebudayaan pada dasarnya bersifat religius. Secara kasar kebudayaan sinonim dengan agama. Keberadaan kebudayaan pada dasarnya adalah inkarnasi agama dalam suatu masyarakat. Kebudayaan tidak dapat berjalan tanpa agama dan sebaliknya. ${ }^{207}$ Paul Tillich juga menyatakan, "agama adalah substansi kebudayaan; kebudayaan adalah bentuk agama...siapa yang dapat membaca gaya sebuah kebudayaan akan dapat menemukan perhatian utama atau substansi religius kebudayaan tersebut". ${ }^{208}$ Namun demikian, menurut Van Der Leeuw hubungan antara agama dengan kebudayaan tidaklah bersifat statis, tetapi dinamis. Menurutnya hubungan itu mengalami empat tingkatan: Pertama, hubungan agama dan kebudayaan sangat erat. Keduanya dianggap sama. Kedua, masa peralihan, yaitu keadaan dimana keduanya masih berhubungan namun sudah semakin menjauh satu sama lain. Ketiga, masa pertikaian yaitu dimana keduanya saling berlawanan untuk menunjukkan dominasinya masing-masing. Keempat, masa pemulihan yaitu perlunya integrasi antara agama dan kebudayaan. ${ }^{209}$ Dengan demikian multietnis dan multireligi menjadi semacam dua sisi mata uang yang tidak terpisahkan untuk dapat memahami multikultur.

\section{Hubungan 'kultur' dan 'teologi'}

Selanjutnya, bagaimanakah hubungan kultur dengan teologi? Menjawab pertanyan ini perlu dipahami beberapa hal berikut yang dikemukakan oleh para teolog.

Pertama, Cornelius Van Til menyatakan,"realita tidak pernah merupakan fakta yang tidak diinterpretasikan. Realita sudah sarat dengan makna karena Tuhan telah menginterpretasikannya. Tugas teolog ialah "berpikir dengan cara pikir Tuhan". ${ }^{210}$ Pernyataan 1948), 28.

207TS Elliot, Notes Toward The Definition of Culture (London: Faber and Faber, 208Paul Tillich, Theology of Culture (London: Oxford University Press, 1959), 4243.

209Verkuyl, 19. 
tersebut menegaskan dua hal, yaitu: adanya interpretasi Allah terhadap realitas dan upaya teolog memahami interpretasi Allah terhadap realitas tersebut.

Tentang realitas yang sudah mengandung makna sebagaimana Allah meinginterpretasikannya menunjukkan bahwa semua realitas (baca: 'budaya') telah diberi makna oleh Tuhan. Makna tersebut merupakan wujud interpretasi Allah. Interpretasi Allah menunjukkan 'cara pikir Allah' dan cara pikir Allah adalah 'Teologi' itu sendiri. Itu berarti bahwa tidak ada satu realitas (budaya) pun yang tidak dipikirkan Tuhan. Apa yang dipikirkan Tuhan itulah 'Teologi'. Jika demikian kebudayaan bukanlah fakta dan aktivitas netral yang bersifat non-teologis. Hal ini mesti dipahami dalam konteks Allah sebagai Pencipta segala sesuatu. Jika mengacu pada hakikat budaya sebagai upaya manusia mengelola sumber daya yang ada pada dirinya dan alam di sekitarnya, maka nampak jelas integrasi teologi dan budaya yang dipersatukan oleh Allah sendiri. Itu berarti secara esensial seuluruh aspek yang terkandung dalam budaya telah memiliki maknanya sendiri sesuai cara pikir Allah. Hal kedua yang ditegaskan van Till yaitu bahwa tugas teolog adalah 'berpikir dengan cara pikir Allah'. Tegasnya, ketika teolog berteologi maka ia harus menemukan makna dari budaya sebagaimana Allah memaknainya. Hal ini mesti ditempuh dengan menemukan cara pikir Allah tentang budaya tersebut. Untuk menemukan cara pikir Allah, maka teolog haruslah mengacu kembali kepada kebenaran Alkitab. Realitas yang tercatat dalam Alkitab merupakan korelasi antara manusia dengan Tuhan yang sarat dengan makna-makna yang Allah maksudkan. Itu berarti, berteologi adalah upaya menemukan kembali (rediscovery) prinsipprinsip interpretasi Allah terhadap budaya, dan mengimplementasikannya ke dalam realitas kekinian. Tugas para teolog ini tidak pernah berakhir selagi ada kehidupan budaya manusia. Merelasikan teks (interpretasi Allah terhadap budaya dalam Alkitab) dan konteks kekinian sebagai realitas budaya yang perlu diinterpretasi berdasarkan prinsip Alkitab.

Kedua, Abraham Kuyper menegaskan, "Saya yakin bahwa yang mendominasi seluruh sistem kehidupan umum adalah interpretasi dari relasi manusia dengan Allah"211 Pernyataan tersebut menegaskan dua frase sekaligus, yaitu: 'sistem kehidupan umum' dan 'interpretasi dari relasi manusia dengan Allah'. Sistem kehidupan umum merupakan

210Kevin J. Vanhoozer, “Dunia Dipentaskan Dengan Baik? Teologi, Kebudayaan dan Hermeneutika" dalam DA Carson dan John Woodbridge, God And Culture (Surabaya: Momentum, 2002), 17.

211lbid., 19. 
Artinya, seluruh aspek kehidupan manusia selalu berkorelasi dengan Theos, dan karenanya tidak ada realitas manusia yang non-teologis. Relasi manusia dengan Allah adalah salah satu aspek dari budaya manusia. Dengan kata lain bahwa yang dimaksudkan dengan 'Sistem kehidupan umum' dapat dimengerti sebagai realitas kebudayaan yang esensinya adalah interpretasi terhadap relasi manusia dengan Allah. Karena itu berteologi berarti upaya menemukan interpretasi relasi manusia dengan Allah.

Ketiga, Yohanes Calvin dikenal dengan teologinya yang bersentral pada 'kedaulatan Allah' atas seluruh aspek kehidupan dan karenanya Kristus juga adalah Tuhan atas kebudayaan, artinya Ketuhanan Kristus berada (berwewenang) di dalam seluruh aspek hidup. ${ }^{212}$ Itu berarti kebudayaan dapat dipahami dalam perspektif baik Teosentris maupun Kristosentris.

Keempat, Kevin J. Vanhoozer, menegaskan bahwa Teologi memiliki tugas penting menjelaskan kebudayaan. Tentang hal ini Vanhoozer menyatakan:

Gereja masa kini justru membutuhkan teologi. Tetapi apa yang diberikan teologi? Bagaimana seharusnya teologi bereaksi terhadap penghancuran cerita, teks dan seluruh kebudayaan? Teologi harus terlibat dalam rekonstruksi kebudayaan. Teologi harus meletakkan fondasi intelektual bagi agama Alkitab yang dipraktekkan. Teologi harus melayani komunitas para penafsir yang percaya bahwa Alkitab adalah saksi tindakan Allah dalam dunia ini dan dalam FirmanNya, Yesus Kristus. Dalam reruntuhan zaman ini, interpretasi Alkitabiah merupakan alat terbaik untuk membangun kembali kebudayaan yang pada awalnya memang dibangun di atas Alkitab. ${ }^{213}$

Penegasan Vanhoozer tersebut mencatat tiga hal penting, yaitu: 1). Teologi harus terlibat dalam rekonstruksi kebudayaan dan menjadi fondasi intelektual bagi praktik religi Alkitab. Ini berarti bahwa konstruksi sebuah kebudayaan harus dibangun dan didasarkan pada sumbangsih teologi di dalamnya. Untuk itu Teologi terus harus berusaha memformulasikan rumusannya guna menyokong konstruksi kebudayaan. Dengan demikian, dalam tugas yang serupa, teologi juga harus turut terlibat dalam merekonstruksi realitas multikultur. 2). Teologi harus berdasar pada realitas tindakan Allah dalam dunia dan melalui Yesus Kristus. 
Ini sama halnya dengan mengatakan bahwa kultur atau multikultur harus dipahami dalam perspektif tindakan Allah secara universal atas dunia ini (dimensi Teosentris) dan dalam perspektif karya Kristus (dimensi Kristosentris). Keduanya mesti dilihat secara seimbang karena kultur telah mengalami sejarah panjang dan tidak lagi dalam keadaan seperti ketika manusia belum berdosa di taman Eden. Memandang kultur secara Teosentris akan memberikan perspektif umum (universal), sedangkan Kristosentris (partikularitas) akan menempatkan budaya dalam konteks penyelamatan. Teologi dan Kristologi tidaklah terpisah dan bertentangan, karena universalitas Allah tidak meniadakan partikularitas Kristus. Demikian juga sebaliknya, partikularitas Kristus tidak meniadakan universalitas Allah. Karena itu tidak perlu dirancang sebuah rumusan Kristologi baru untuk disesuaikan dengan kebutuhan masa kini seperti yang dikemukakan Th. Sumartana demikian:

Pertanyaan yang utama dalam ajaran Kristen adalah bagaimana kita menempatkan dan memikirkan hubungan antara kristologi dan teologi. Kristologi kita anggap sebagai bagian dari keunikan partikulariat sedang teologi bagian dari universalitas. Soalnya adalah bagaimana kita menafsirkan kristologi secara baru sehingga mampu memberi tempat bagi agama-agama? Secara umum bisa kita katakan bahwa kristologi yang ada tidak dirumuskan dalam konteks pluralisme agama-agama seperti yang sekarang ini. Mungkin disinilah tepatnya kita mengatakan bahwa yang kita butuhkan adalah teologi agama-agama dan bukan kristologi agama-agama. Sebab, tekanan yang hendak kita berikan adalah universalitas itu. ${ }^{214}$

Dengan menekankan Teologi, Sumartana akhirnya justru harus memisahkan Kristologi. Ini dapat berakibat pada hilangnya hakikat keunikan Kristus demi agama-agama lain. Ketiga, interpretasi Alkitabiah merupakan alat terbaik untuk membangun kembali kebudayaan. Ini hendak menegaskan bahwa Teologi yang dipakai sebagai fondasi rekonstruksi kebudayaan haruslah merupakan hasil dari interpretasi Alkitabiah. Artinya bahwa Teologi itu haruslah Alkitabiah. Demikian juga mengenai multikultur haruslah mendapatkan dukungan secara Alkitabiah.

214Th. Sumartana, “Theologia Religionum” dalam Tim Balitbang PGI, Meretas Jalan Teologi Agama-Agama (Jakarta: BPK Gunung Mulia, 2000), 23. 
Ketiga catatan tersebut di atas berguna untuk merancang bangun sebuah 'Teologi Multikultural' yaitu,“Teologi yang dibangun berdasarkan hasil interpretasi Alkitabiah (PL dan PB) mengenai cara pikir dan tindakan Allah dan Kristus terhadap realitas multikultur (ragam budaya: multietnis dan multireligi) manusia." Dengan kata lain, 'Teologi Multikultural' adalah teologi yang merumuskan bagaimana pikiran, sikap dan tindakan Allah terhadap fenomena multikultur baik secara umum sebagai Pencipta dan Penguasa segala ciptaan, maupun sebagai Juruselamat (Kristus) manusia berdosa.

Secara khusus Teologi Multikultural hendak memberi perhatian pada masalah kebudayaan yang menyangkut masalah 'hubungan manusia dengan sesamanya' ${ }^{215}$ Hal ini juga dikemukakan oleh D.A. Peransi seperti dikutip oleh L. Sihombing yang menyatakan,"salah satu unsur terpenting dalam kebudayaan adalah pandangan yang hidup dalam suatu kebudayaan tentang hakikat manusia, hubungan antar manusia serta sangkan parannya". 216 'Hubungan antar sesama manusia' (antar etnis dan antar religi) ini merupakan masalah yang harus mendapatkan jawaban secara teologis, seperti dikemukakan oleh Olaf H. Schumann demikian:

Salah satu masalah teologis konkret dan kontekstual sekarang dan yang teramat penting serta memerlukan penjelasan mantap ialah: bagaimana kita harus bersikap terhadap orang lain di luar umat kita, yang dulunya disebut orang asing atau kafir? Bagaimana ia harus dinilai menurut iman (Kristen)? ...pengajaran Kristen Protestan (Teologi) tentang agama-agama jika dilakukan secara tepat dan benar harus memungkinkan dinamika ini, mengubah mentalitas getho yang penuh ketakutan dan perlawanan terhadap orang lain menjadi respek keterbukaan dan cinta kasih. Pengajaran seperti ini dapat dikatakan "misioner" karena menyumbangkan sesuatu yang sifatnya kristiani... ${ }^{217}$

215Koentjoroningrat, 34. Menurut Strodbeck (Sosiolog) dan Kluckkholm (Antropolog) seperti dikutip Koentjoroningrat mencatat bahwa ada lima masalah utama yang menyangkut nilai budaya, yaitu: masalah hakikat hidup manusia, masalah hakikat karya manusia, masalah hakikat dan kedudukan manusia dalam ruang dan waktu, masalah hubungan manusia dengan alam sekitar, masalah hubungan manusia dengan sesamanya.

216 L. Sihombing, Kultus dan Kultur ( Batu-Malang: STT "I-3", 1997), 80.

217Olaf H. Schumann, Menghadapi Tantangan Memperjuangkan Kerukunan (Jakarta: BPK Gunung Mulia, 2006), 122-123, 129. 
Realitas perbedaan etnis dan agama memang harus mendapatkan penjelasan teologis yang memadai. Pertanyaan siapakah 'sesama manusia yang beda etnis dan agama' dan bagaimana harus berelasi dengan mereka? harus dijawab secara teologis. Namun demikian usaha Schumann menjawab pertanyaan tersebut dalam konteks pluralitas agama di Indonesia bisa kebablasan. Ia menempuh jalan dialog teologis untuk mencoba memahami kebenaran 'kita' dalam perspektif agama lain, demikian juga sebaliknya. Dalam dialog itu masingmasing agama berdiri pada pandangan agamanya sendiri, namun Schumann menambahkan bahwa,"posisi semacam itu tidak boleh menjadi dogma kaku, melainkan ia harus dinamis untuk dapat menyesuaikan dan mewujudkan diri dalam situasi yang berubah-ubah". ${ }^{218}$ Dalam hal ini nampak bahwa acuan utama dalam dialog bukan pada keabsahan teologi Kristen melainkan bergantung kepada kondisi (kebutuhan) yang berubah-ubah. Jika demikian kebenaran-kebenaran Kristiani sebagai kebenaran absolut akan terancam kekhasannya.

Untuk itulah diperlukan Teologi Multikultural yang akan memberi acuan teologis bagi orang percaya untuk berpikir, bersikap dan bertindak terhadap sesamanya manusia yang berbeda 'etnis' dan 'religi' berdasarkan Alkitab dalam perspektif Teosentris sekaligus Kristosentris. Perspektif Teosentris (universal) dapat mengacu kepada kebenaran-kebenaran Kosmologis (Mandat Budaya), Antropologis (manusia sebagai gambar dan rupa Allah), Teologis (Kedaulatan Allah, Providensia Allah, Keadilan Allah dan Kekudusan Allah). Sedangkan dimensi Kristosentris (Partikular) mengacu kepada aspek-aspek: Inkarnasi, Univeralitas Soteriologi, Teokrasi-Presentis, Universalitas Pneumatologis, Naturalitas Gereja dan Multikulturalitas Eskatologis.

\section{Penutup:}

Berbudaya dan berteologi tidak dapat dipisahkan. Berteologi merupakan bagian integral dari berbudaya. Teologi memiliki tanggung jawab merekontruksi budaya. Budaya masa kini berada dalam paradigma Multikultural. Masyarakat multikultural sarat dengan berbagai konflik etnik dan religi. Konflik etnik dan religi tersebut perlu solusi multidimensi 
termasuk solusi teologis teologis. Diusulkan sebuah upaya teologis unytuk meretas rancang bangun Teologi Multikultural yang berbasis pada dimensi Teosentris dan Kristoisentrin. Dimensi Teosentris bermaksud guna memberi ruang bagi prinsip-prinsip universal sehingga berguna dalam membangun komunikasi dengan berbagai pihak yang berbeda. Sedangkan dimensi Kristosentris bermaksud mempertahankan nilai-nilai khas kristiani. Keseimbangan kedua dimensi tersebut memberi dasar bagi upaya berelasi dengan semua pihak yang berbeda tanpa harus meniadakan kekhasan iman Kristen. 


\section{BIBLIOGRAFI}

B. Zuck, Roy, A Biblical Theology of The Old Testament, Malang: Gandum Mas, 2005.

Babcock Gove, Philip (Ed.), Webster's Third New International Dictionary, USA: meriam Inc. Publisher, 1983

Brown, Francis., SR Driver dan Charles A. Briggs, A Hebrew and English Lexicon of the

Elliot, T.S., Notes Toward The Definition of Culture, London: Faber and Faber, 1948.

Geertz, Clifford, Kebudayaan dan Agama, Yogyakarta: Kanisius, 1992.

Grunlan, Stephen \& Reiner, Milton (ed.), Christian Perspective on Sociology, Grand Rapids, Michigan: Zondervan Publishing House, 1982.

H. Schumann, Olaf, Menghadapi Tantangan Memperjuangkan Kerukunan, Jakarta: BPK Gunung Mulia, 2006.

H. Kraft, Charles., Christianity in Culture: A Study in Dynamic Biblical Theologizing in Cross Cultural Perspective, New York: Orbis Book, 1992.

J. Vanhoozer, Kevin, "Dunia Dipentaskan Dengan Baik? Teologi, Kebudayaan dan Hermeneutika" dalam DA Carson dan John Woodbridge, God And Culture (Surabaya: Momentum, 2002).

Koentjoroningrat, Kebudayaan Mentalitet dan Pembangunan, Jakarta: PT Gramedia, 1979.

Larkin Jr., William J., Culture and Biblical Hermeneutic, Grand Rapids: Baker Book House, 1988.

Lingenfelter, Sherwood Transforming Culture: A Challenge for Christian Mission, Grand Rapids: Baker Book House, 1992. 
Luzbetak, Louis, The Church and Cultures, Pasadena: William Carey Library,1970.

Mc Gavran, Donald The Clash Between Christianity and Culture, Washington: Canon Press, 1974.

Munir Mulkhan, Abdul "Pendidikan Monokultur Versus Multikultural dalam Politik" dalam Kompas, 28 September 2004 (Ed. KS).

Nieburh, H. Richard, Christ and Culture. New York: Harper and Row, Harper Torchbooks, 1956.

Old Testament, Oxford: Claredon, 1962.

Octavianus, Petrus, Identitas Kebudayaan Asia Dalam Terang Firman Allah, Batu-Malang: YPPII, 1985.

S. Keener, Craig, The IVP Bible Background Commentary New Testament, Illinois: Inter Varsity Press, 1993.

Sihombing, L., Kultus dan Kultur, Batu-Malang: STT 'I-3”, 1997.

Sitompul, A. A.,Manusia dan Budaya, Jakarta: BPK Gunung Mulia, 1991.

Sumartana,Th., “Theologia Religionum” dalam Tim Balitbang PGI, Meretas Jalan

Tillich, Paul, Theology of Culture, London: Oxford University Press, 1959.

Tong, Stephen, Dosa dan Kebudayaan. Surabaya: Momentum, 2007.

H. Schumann, Olaf, Menghadapi Tantangan Memperjuangkan Kerukunan, Jakarta: BPK Gunung Mulia, 2006.

Verkuyl, J., Etika Kristen: Kebudayaan, Jakarta: BPK Gunung Mulia, 1982. 